\title{
Risk factors for long-stay in an I talian acute psychiatric ward: a 7-year retrospective analysis
}

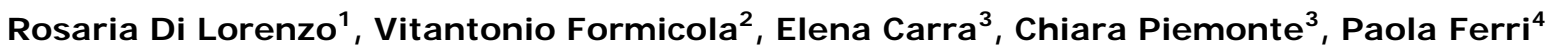 \\ 1. Psychiatrist, Servizio Psichiatrico Diagnosi e Cura (SPDC), Az-USL Modena, Italy. 2. Servizio Psichiatrico Diagnosi e Cura, \\ Az-USL Modena, Italy. 3. Residents in Psychiatry, School of Specialization in Psychiatry, University of Modena and Reggio \\ Emilia, Italy. 4. School of Nursing, University of Modena and Reggio Emilia, Italy
}

Correspondence: Rosaria Di Lorenzo, MD. Address: Servizio Psichiatrico Diagnosi e Cura (SPDC), Az-USL Modena, Italy. Email: saradilorenzo1@alice.it.

Received: February, 2013

DOI : $10.5430 /$ jnep.v4n1p68
Accepted: April 2, $2013 \quad$ Online Published: June 5, 2013

URL: http://dx.doi.org/10.5430/jnep.v4n1p68

\section{Abstract}

Background: In West during the last decades, the phenomenon of "bed blockers" has been more frequently investigated, probably because of increasing economic constraints in the management of public health. According to most authors, the lack of rehabilitation facilities, organizational problems within the hospital, the long wait for medical consultations and diagnostic procedures would be the main causes of "delayed discharge". Early studies were carried out in long-term care, rehabilitation and post-acute geriatric wards. In Psychiatry, the few studies on this topic highlighted a wide range of causes, including both patient conditions and organizational health system problems. In Italy, the problem of psychiatric delayed discharges has become more pressing after the $180 \mathrm{Law}$, which established the closure of all psychiatric hospitals and implemented psychiatric wards inside General Hospitals to admit only 15 acute patients for a very short period. Purposes: To highlight the phenomenon of long-stay in an acute psychiatric ward and to relate it to demographic, clinical and organizational variables.

Methods: The survey was conducted in the 15-bed public psychiatric ward of Modena (Italy). All admissions were retrospectively collected from the database of the Department from 1 January 2005 to 31 December 2011 (3981 hospitalizations with an average stay of 12.49 days). Demographic data, clinical variables, inpatient care problems, discharge programs were statistically related to the duration of admissions (survival analysis: log-rank test, Kaplan-Meier curves). The 3981 hospitalizations were divided into two groups according to the $90^{\circ}$ percentile of duration: $<27$ days $(\mathrm{n}=3575)$ and $\geq 27$ days $(\mathrm{n}=406)$ and the variables of the two groups were compared (multiple logistic regression). Secondary analysis was conducted on the subgroup of the longest hospitalizations further divided into two groups according to the $90^{\circ}$ (from 27 days to $<36$ days) and $95^{\circ}$ percentile ( $\geq 36$ days), in order to find out variables related (survival analysis: log-rank test; multiple logistic regression test).

Results: The longest hospitalizations ( $\geq 27$ days) represent $11 \%$ of all admissions during the observation period. When all variables are compared to the duration of hospitalizations, most of them are statistically significantly related to the length of hospitalizations, but, when statistical analysis was focused on the comparison between the two groups of the longest hospitalizations, a smaller number of variables ("gender", "age", "rehabilitative programs", "extra-psychiatric clinical activities", "pharmacotherapy" and "aggressiveness of patient") were identified by survival analysis as statistically significant correlates of long-stay (log-rank test), whereas only "female gender" and "aggressiveness pf patient" were the 
variables statistically significantly related to the length of hospitalizations evidenced by multivariate logistic regression analysis.

Conclusions: Our results suggest that a wide range of factors may be responsible for the delayed discharges in psychiatry as most previous studies have already shown. However, only few factors were related to the longest duration of hospitalization and, among these, aggressiveness was the only one statistically significant correlate to long-stay in all statistic tests. This data confirms the clinical observation that aggressive behaviour can be sufficient by itself to explain the difficulty of discharging.

\section{Key words}

Risk factors, Long-stay, Acute psychiatric ward

\section{Introduction}

\subsection{Background}

Since the 1950s, researchers have been interested in the phenomenon of patients who blocked a bed improperly because they could not be discharged from a hospital despite good clinical compensation achieved, due to issues not directly related to clinical diseases. So that, the term "bed blockers" appearing in the literature in the 70 s indicated those patients who, after completing diagnostic treatment, continued to occupy a bed, often waiting for alternative accommodations in order to continue outpatient care ${ }^{[1]}$. Subsequently, the term "bed blockers" was judged an unethical label for patient ${ }^{[2]}$ and limitative as it emphasized exclusively patient related factors. Other terms such as "delayed discharge", "delayed transfer of care" ${ }^{[3]}$ and "long-stay" ${ }^{[4-6]}$, were therefore preferred, because they included not only clinical factors, but also health and social organizational problems responsible for delayed discharges in many cases ${ }^{[7]}$.

In West during the last decades, the phenomenon of "bed blockers" has been more frequently investigated, probably because of increasing economic constraints in the management of public health. In particular, the hospital has become a system characterized by a chronic lack of beds, so that even a small reduction in length of hospital stay may improve the capacity to accept new acute patients. In this regard, the first nations that faced this phenomenon were Sweden, Denmark and England. In Sweden, the "Elderly Reform" of $1992^{[8]}$ and in England, the "Community Care Act" of $2003{ }^{[9]}$, in cases of delayed discharges, established a financial sanction for social service considered responsible for prolongation of hospitalization due to inefficient management of outpatient care ${ }^{[10]}$. These reforms made possible to reduce significantly long hospitalizations, especially in geriatric environments. Most authors put in evidence that efficient discharge management can lead to both a reduction of costs for single admission and a more appropriate allocation of resources, useful to the exclusive treatment of acute patients in hospital ${ }^{[11]}$. In addition, a prolonged stay exposes the patient to the risk of iatrogenic diseases associated with long hospitalization, like hospital infections, decreased daily living activities, psychological dependency on institutions and depressive symptoms ${ }^{[10]}$.

According to many English authors, the lack of rehabilitation facilities, organizational problems within the hospital, the long wait for medical consultations and diagnostic procedures would be the main causes of "delayed discharge" ${ }^{[12]}$. A systematic review highlights the importance of careful discharge planning to reduce this phenomenon ${ }^{[13,14]}$. According to the Joint Commission Accreditation Health Organization, discharge planning is "the formalized process in health care organizations that operates a program of continuity of care through a specific follow-up for each patient. The discharge plan identifies a sequence of phases which needs to be implemented in time in order to achieve goals like safe return home and continuity of care. The discharge plan can ensure that the patient remains hospitalized only for clinical problems" ${ }^{[15,16]}$. Other studies point out that clear and comprehensive communication among hospital professionals, patients, family members, case managers and community services is necessary to apply an effective discharge program ${ }^{[17]}$. Many authors investigated the geriatric field and evidenced the importance of intermediate structures in helping to reduce prolonged hospitalizations ${ }^{[18-23]}$, since, although many geriatric patients did not present acute illness, they still required intense treatment and rehabilitative therapy ${ }^{[24-27]}$. Early studies were carried out in long-term care, rehabilitation and 
post-acute geriatric wards and focused on elderly populations ${ }^{[1,28-33]}$, patients with physical and intellectual disabilities and chronic patients with severe social problems ${ }^{[34,35]}$.

\subsection{Causes of long-stay hospitalizations}

All studies were unanimous in indicating two important factors as non-clinical causes of delayed discharges ${ }^{[36]}$ :

(1) health care organizational problems due both to more highly specialized clinical treatment and complex community services;

(2) economic issues related to the need to reduce social services costs in spite of increased requests for social support from the elderly and social outcasts.

The literature indicates the following organizational factors: 1) delays in the delivery of diagnostic and therapeutic

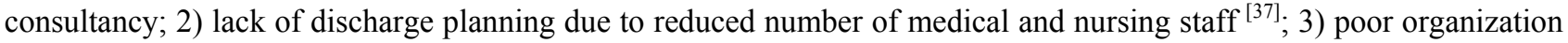
within the physician team ${ }^{[38]}$; 4 ) insufficient communication among community services; 5) delayed assessment by social services ${ }^{[39]}$; 6) lack of family support at discharge ${ }^{[14]}$;7) lack of intermediate care facilities ${ }^{[10]}$; 8) long waiting lists for admission to an intermediate care facility ${ }^{[40]}$.

In accordance with most researches, "difficult" discharges appear to be a critical problem whose solution requires not only the review of hospital organization, but also, and most importantly, improved integration between public and private services that provide community health care and social services. In this regard, most authors have highlighted the importance of "intermediate" services between the hospital and community care in order to reduce overcrowding in hospital wards and, at the same time, to provide a versatile health care system ${ }^{[28]}$.

The phenomenon of "bed blockers" has also been interpreted as a lack of appropriateness of care, which regards both the clinical characteristics of patients and therapeutic services provided. To determine the appropriateness of hospital admissions and their duration, several studies have applied the "Appropriateness Evaluation Protocol" (AEP), developed in the late $1970 \mathrm{~s}{ }^{[41]}$ and subsequently revised in the 1980s ${ }^{[42,43]}$. Through this instrument it has been shown that inappropriate cause of hospitalization often overlaps an inappropriate extension of stay ${ }^{[37,38,44-46]}$. As shown in the literature, the problems that contribute to delayed discharges are varied and difficult to solve, but apparently closely related to the organization of outpatient services and the hospital ${ }^{[24]}$. To explain this phenomenon, many authors have emphasized the importance of the local context in health care policy and organization ${ }^{[12]}$.

\subsection{Delayed discharges in psychiatry}

Studies on this topic are few and difficult to compare due to the variability of health care organization systems. One of the first articles pointed out that the phenomenon of delayed discharges in a sample of 138 patients admitted to a Canadian hospital accounted for $35 \%$ of all discharges. Delayed discharge patients differed from correctly discharged patients only for social reasons since they represented the poorest section of the population ${ }^{[47]}$.

Other studies highlighted that the percentage of delayed discharges in psychiatry ranged from $27 \%$ to $58 \%$. All reasons were related to difficulties in discharging and were frequently represented by patient refusal of an assistance program and by patient conditions of loneliness and social maladjustment ${ }^{[48,49]}$. Another Canadian study analyzed the factors related to delayed discharges and found out that lack of residential care and long waiting lists to get into a protected facility constituted the organizational reasons, whereas schizophrenia represented a clinical cause ${ }^{[50]}$. Poor living conditions, such as homeless shelters, significantly increased inappropriate long-term stay in a psychiatric hospital, according to a British study ${ }^{[11]}$.

The first research on this phenomenon revealed that symptom severity and the lack of extra-hospital services were the most frequent causes of delayed discharges ${ }^{[50]}$. In following research, the lack of hospital alternatives was the most common motivation, whereas other factors, such as organic comorbidity and old age, represented further risk factors for lengthening of hospitalization ${ }^{[52]}$. Other authors have shown that, but some clinical dimensions, such as hostility and 
manic excitement, not psychiatric diagnosis were positively related to the length of hospitalization ${ }^{[53]}$. Other previous studies had shown that violence during hospitalization could be one of the most important risk factors for prolonged hospitalization ${ }^{[54]}$.

\subsection{Purposes}

(1) To highlight the phenomenon of long-stay hospitalizations in an Italian acute psychiatric ward.

(2) To evaluate the demographic, clinical and organizational variables related to lengthening of hospitalizations.

\section{Patients and methods}

The survey was conducted in the 15-bed public psychiatric ward, the so called Servizio Psichiatrico di Diagnosi e Cura (SPDC), of Modena City, located in the general university hospital Nuovo Ospedale Civile S.Agostino Estense (N.O.C.S.A.E.), which receives all patients from Modena and Castelfranco Emilia (population 250,000) affected by acute psychiatric diseases, admitted in compulsory or voluntary state. According to Italian $180 \mathrm{Law}^{[55]}$, patients in psychiatric compulsory state have to be admitted to the public psychiatric wards called SPDC, which have to be located in a general hospital.

We retrospectively collected all admissions recorded in the database of the Department from 1 January 2005 to 31 December 2011. We observed: 3981 hospitalizations with on average stay of 12.49 days, 2168 patients hospitalized, 1.84 hospitalizations per patient during the observation period.

The following variables were analyzed:

- the demographic data (age, gender, nationality);

- the clinical variables [psychiatric and organic diagnosis, according to International Classification of Diseases, 9th Revision, Clinical Modification (ICD-9-CM) ${ }^{[56]}$, mono and poly psycho-pharmacotherapy, compulsory and voluntary state of admission];

- the extra-psychiatric clinical activities, evaluated as present or absent (consultations, diagnostic tests, pharmacotherapy);

- the rehabilitation programs and activation of community service network (Mental Health Service, Social Service, Drug Addiction Service, etc.), evaluated as present or absent;

- the need for physical restraints and/or intervention of security hospital guards due to aggressiveness of patient;

- the discharge modalities (ordinary, self-discharge, transfer to protected facilities or to other hospital wards).

The variables were statistically correlated with the duration of admissions in order to evidence significant associations (survival analysis: log-rank test, Kaplan-Meier curves) ${ }^{[57]}$.

The 3981 hospitalizations were divided into two groups according to the $90^{\circ}$ percentile of duration: $<27$ days $(\mathrm{n}=3575)$ and $\geq 27$ days $(\mathrm{n}=406)$. The above reported variables of the two groups were compared (multivariate logistic regression test) ${ }^{[57]}$.

Secondary analysis was conducted on the subgroup of the longest hospitalizations with a duration of $\geq 27$ days, according to the $90^{\circ}$ percentile, in order to highlight what variables were related to the lengthening of hospitalizations (survival analysis: log-rank test). This subgroup was further divided into two groups according to the $95^{\circ}$ percentile of duration: the first one $(n=205)$ with the duration from 27 to $<36$ days and the second one $(n=203)$ with $\geq 36$ day duration and their respective variables compared (multivariate logistic regression test). 
The statistical analysis was conducted by means of STATA 12 program (2011).

\section{Results and discussion}

The longest hospitalizations with a duration $\geq 90^{\circ}$ percentile ( $\geq 27$ days) represent $11 \%$ of all hospitalizations during the 7-year observation period and can be considered long-stay admissions in our ward, since the average duration of hospitalization in our ward is much shorter.

The demographic data of patients admitted to our ward are shown in the table 1, the psychiatric diagnosis and organic comorbidity of our sample in the table 2 and the variables related to hospitalizations in the table 3.

Table 1. Demographic variables of our sample $(n=3981)$

\begin{tabular}{llll}
\hline VARIABLES & & $\mathbf{N}(\mathbf{\%})$ & LOG-RANK TEST \\
\hline \multirow{2}{*}{ GENDER } & female & $1865(47 \%)$ & Chi2 $=22.76$ \\
& male & $2116(53 \%)$ & $p<0.001$ \\
\multirow{2}{*}{ NATIONALITY } & Italian & $3300(83 \%)$ & Chi $2=1.31$ \\
& Non-Italian & $681(17 \%)$ & NS \\
PLACE OF & Modena & $3072(77 \%)$ & Chi $2=301.71$ \\
RESIDENCE & Italy (excluding Modena) & $702(18 \%)$ & $p<0.0001$ \\
& Foreign country & $182(4.5 \%)$ & \\
\hline
\end{tabular}

All variables, excluding "nationality" and "Anxiety Disorders", are statistically significantly related to the lengthening of hospitalizations if each variable is singularly compared to duration (log-rank test, $p<0.001$ ) (see Table $1,2,3$ ).

Female gender is related to the lengthening of hospitalizations, as the Kaplan-Meier curve of "gender" shows (see Figure 1). The distribution of "age" according to gender evidences that female patients were 45 years old $(\mathrm{SD}=16.21)$ and male patients 42 years old $(\mathrm{SD}=14.75)$ on average (see Figure 2). In this regard, we highlight that the mean age (43 years) of patients admitted for $<27$ days was statistically significantly inferior to the mean age (45 years) of patients admitted for $\geq$ 27 days ( $t$-test, $p<0.05$ ) (see Figure 3).

Table 2. Psychiatric diagnosis and organic comorbidity $(\mathrm{n}=3981)$

\begin{tabular}{llll}
\hline VARIABLES & & N (\%) & LOG-RANK TEST \\
\hline & Organic Psychotic Disorders & $260(6.53 \%)$ & \\
& Substance Pathological Use & $428(10.75 \%)$ & \\
& Schizophrenia and other Psychotic Disorders & $1429(35.90 \%)$ & \\
PSYCHIATRIC & Manic Episode in Bipolar Disorders & $298(7.49 \%)$ & \\
DIAGNOSIS & Major Depressive Episode in Bipolar Disorders & $353(8.87 \%)$ & Chi2 $=195.26$ \\
(ICD-9-CM) $§$ & Personality Disorders & $516(12.96 \%)$ & $p<0.001$ \\
& Dysthymic Disorder and Adjustment Reaction & $421(10.58 \%)$ & \\
& Anxiety Disorders & $136(3.42 \%)$ & \\
& Mental Retardation & $87(2.19 \%)$ & \\
ORGANIC & Eating Disorders and other Disorders & $53(1.33 \%)$ & \\
COMORBIDITY & present & $766(19.23 \%)$ & Chi2 $=54.93$ \\
\hline
\end{tabular}


Table 3. Variables related to hospitalizations $(n=3981)$

\begin{tabular}{|c|c|c|c|}
\hline VARIABLES & & N. (\%) & LOG-RANK TEST \\
\hline \multirow{2}{*}{ STATE OF ADMISSION } & voluntary & $3060(76.88 \%)$ & \multirow{2}{*}{$\begin{array}{l}\text { Chi2 }=153.28 \\
p<0.001\end{array}$} \\
\hline & compulsory & $921(23.12 \%)$ & \\
\hline \multirow{3}{*}{ PSYCHO-PHARMACOTHERAPY } & non- pharmacother & $89(2.31 \%)$ & \multirow{3}{*}{$\begin{array}{l}\text { Chi2 }=171.01 \\
p<0.001\end{array}$} \\
\hline & monotherapy & $595(14.93 \%)$ & \\
\hline & polytherapy & $3297(82.76 \%)$ & \\
\hline \multirow{2}{*}{ REHABILITATION PROGRAMS } & present & $1631(40.94 \%)$ & \multirow{2}{*}{$\begin{array}{l}\text { Chi2 }=389.87 \\
p<0.001\end{array}$} \\
\hline & absent & $2350(59.06 \%)$ & \\
\hline \multirow{2}{*}{$\begin{array}{l}\text { EXTRA-PSYCHIATRIC CLINICAL } \\
\text { ACTIVITIES }\end{array}$} & present & $1912(48.02 \%)$ & \multirow{2}{*}{$\begin{array}{l}\text { Chi2 }=287.04 \\
p<0.001\end{array}$} \\
\hline & absent & $2069(51.98 \%)$ & \\
\hline \multirow{2}{*}{ AGGRESSIVENESS OF PATIENT } & present & $538(14 \%)$ & \multirow{2}{*}{$\begin{array}{l}\text { Chi2 }=59.14 \\
p<0.001\end{array}$} \\
\hline & absent & $3443(86 \%)$ & \\
\hline \multirow{2}{*}{$\begin{array}{l}\text { ACTIVATION OF COMMUNITY } \\
\text { SERVICE NETWORK }\end{array}$} & present & $2737(68.7 \%)$ & \multirow{2}{*}{$\begin{array}{l}\text { Chi2 }=517.30 \\
p<0.001\end{array}$} \\
\hline & absent & $1244(31.30 \%)$ & \\
\hline \multirow{4}{*}{ MODALITIES OF DISCHARGE } & self-discharge & $333(8.43 \%)$ & \multirow{4}{*}{$\begin{array}{l}\text { Chi2 }=427.99 \\
p<0.001\end{array}$} \\
\hline & ordinary & $1996(50.10 \%)$ & \\
\hline & $\begin{array}{l}\text { transfer to protected } \\
\text { facilities }\end{array}$ & $548(13.76 \%)$ & \\
\hline & $\begin{array}{l}\text { transfer to other hospital } \\
\text { wards }\end{array}$ & $1104(27.71 \%)$ & \\
\hline
\end{tabular}

The "aggressiveness of patients" (see Figure 4) and "ordinary discharge" or "transfer to protected facilities" (see Figure 5) represented risk factors for the lengthening of hospitalizations.

If all variables are compared to duration of hospitalization by means of multivariate logistic regression test, the following variables "female gender" $(p<0.001)$, "place of residence: Modena" $(p<0.001)$, all (excluding "Anxiety Disorders") psychiatric diagnosis $(p<0.05 ; p<0.001)$, the presence of "organic comorbidity" ( $p<0.001)$, "rehabilitative programs" $(p<0.001)$, "extra-psychiatric clinical activities" $(p<0.001)$, "aggressiveness of patients" $(p<0.001)$ and "activation of inand outpatient care network" ( $p<0.001)$, "voluntary state of admission" $(p<0.001)$, self-discharge $(p<0.01)$ and transfer to other wards $(p<0.05)$ among the "modalities of discharge" are statistically significantly related to the duration of hospitalization (see Table 4).

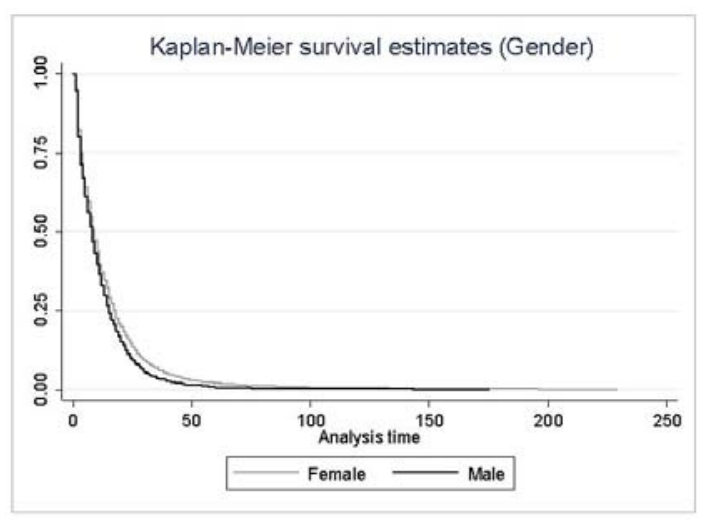

Figure 1. The relationship of "gender" with the length of hospitalizations in the whole sample 


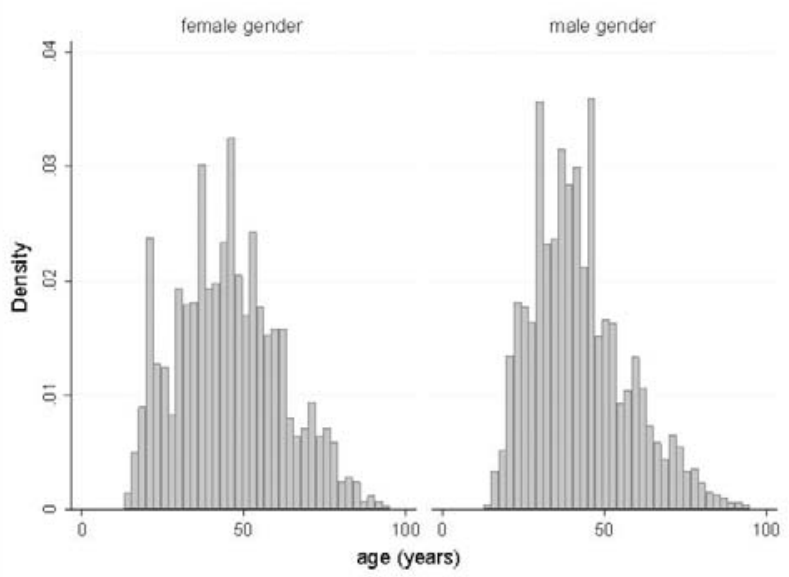

Figure 2. The distribution of "age" divided by "gender" in the whole sample

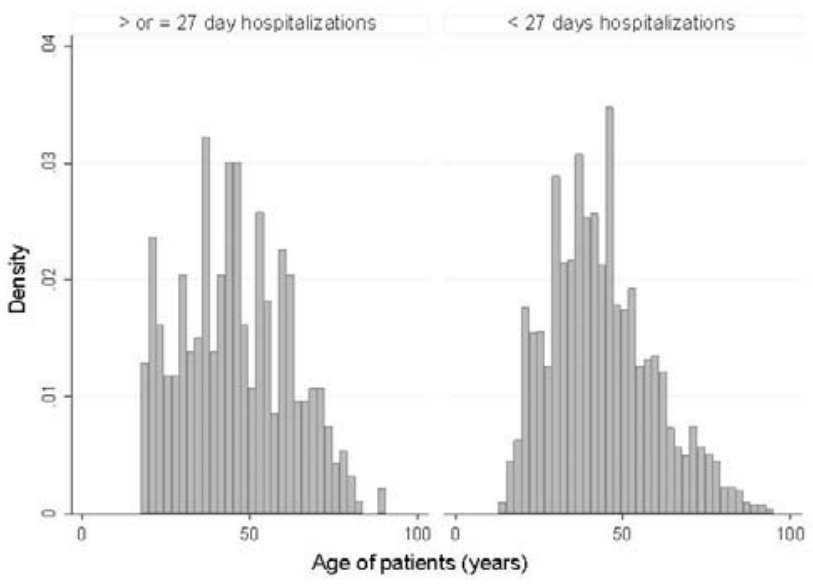

Figure 3. The distribution of "age" in the two groups of hospitalizations ( $<27$ and $\geq 27$ days)

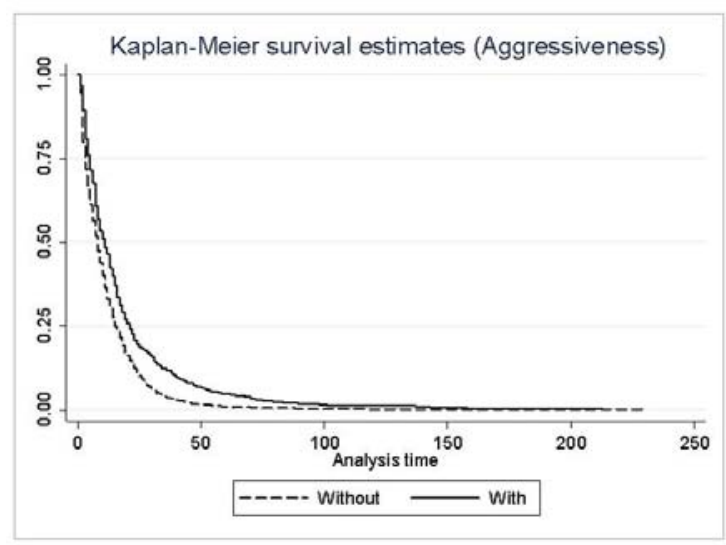

Figure 4. The relationship of "aggressiveness of patients" with the length of hospitalizations in the whole sample 


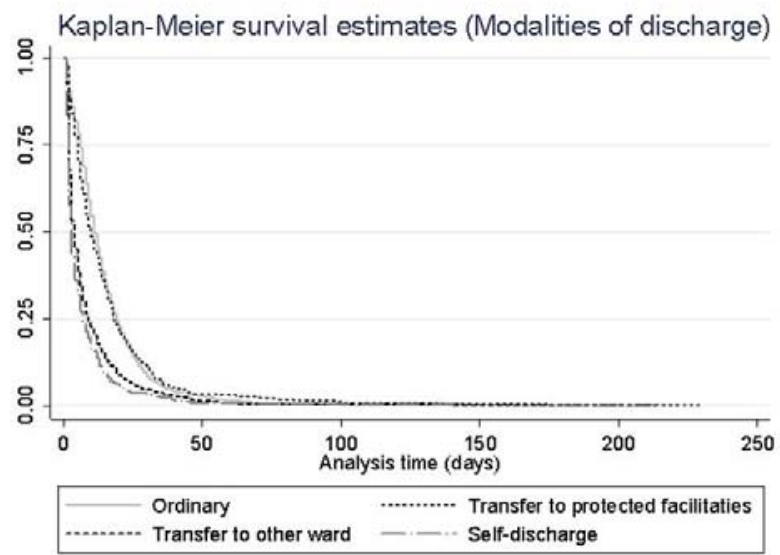

Figure 5. The relationship of "modalities of discharges" with the length of hospitalizations in the whole sample (n=3981)

Table 4. Variables related to length of hospitalizations in the whole sample ( $\mathrm{n}=3981)$ (multivariate logistic regression test)

\begin{tabular}{|c|c|c|c|}
\hline Variables & Odds ratio & Probability & $95 \%$ confidence interval \\
\hline Gender: female & 1.49 & $p<0.001$ & $1.1885-1.8736$ \\
\hline Place of residence: Modena & 3.08 & $p<0.001$ & $1.8596-5.1194$ \\
\hline \multicolumn{4}{|l|}{ Psychiatric Diagnosis: } \\
\hline Mental Retardation & 0.19 & $p<0.005$ & $0.0658-0.5515$ \\
\hline Substance Pathological Use and related disorders & 0.35 & $p<0.005$ & $0.1657-0.7484$ \\
\hline Schizophrenia and other Psychotic Disorders & 0.24 & $p<0.001$ & $0.1211-0.4610$ \\
\hline Manic Episode in Bipolar Disorders & 0.22 & $p<0.001$ & $0.1075-0.4656$ \\
\hline Major Depressive Episode in Bipolar Disorders & 0.20 & $p<0.001$ & $0.0955-0.4254$ \\
\hline Personality Disorders & 0.36 & $p<0.01$ & $0.1734-0.7515$ \\
\hline Dysthymic Disorder and Adjustment Reaction & 0.35 & $p<0.01$ & $0.1638-0.7672$ \\
\hline Eating Disorders and other disorders & 0.32 & $p<0.05$ & $0.1161-0.8996$ \\
\hline Organic comorbidity: present & 1.60 & $p<0.001$ & $1.2269-2.0846$ \\
\hline State of admission: voluntary & 2.22 & $p<0.001$ & $1.7494-2.8308$ \\
\hline Rehabilitation programs: present & 0.39 & $p<0.001$ & $0.3063-0.5003$ \\
\hline Extra-psychiatric clinical activities: present & 0.45 & $p<0.001$ & $0.3513-0.5838$ \\
\hline Aggressiveness of patient: present & 0.51 & $p<0.001$ & $0.3817-0.6728$ \\
\hline Activation of community service network: present & 0.36 & $p<0.001$ & $0.2421-0.5282$ \\
\hline \multicolumn{4}{|l|}{ Modalities of discharge: } \\
\hline self- discharge & 2.22 & $p<0.01$ & $1.1749-4.1828$ \\
\hline transfer to other wards & 1.43 & $p<0.02$ & 1.0383-1.9709 \\
\hline
\end{tabular}

The survival analysis focused on the comparison of the longest hospitalizations ( $\geq 27$ days), divided into two groups according to the $95^{\circ}$ percentile (from $\geq 27$ days to $<36$ days and $\geq 36$ days), evidenced that "gender" ( $p<0.05$ ), "age" $(p<0.05)$, "rehabilitative programs" $(p<0.01)$, "extra-psychiatric clinical activities" $(p<0.005)$, "pharmacotherapy" $(p<0.05)$ and "aggressiveness of patient" $(p<0.001)$ were the variables statistically significantly related to the longest duration of admissions (log-rank test), whereas the multivariate logistic regression test shows that only "female gender" $(p<0.05)$ and "aggressiveness of patient" $(p<0.005)$ were statistically significantly related to the lengthening of hospitalizations (see Table 5). 
Table 5. Variables related to length of hospitalizations in the subgroup of the longest hospitalizations $(\mathrm{n}=406$ ) (multivariate logistic regression test)

\begin{tabular}{lcll}
\hline Variables & Odds ratio & Probability & 95\% confidence interval \\
\hline Gender: female & 1.641638 & $p<0.05$ & $1.053298-2.558605$ \\
Aggressiveness: present & 2.169888 & $p<0.005$ & $1.283465-3.668518$ \\
\hline
\end{tabular}

When we analyzed the whole sample, we found that most variables were related to length of hospitalizations. This relationship can be explained by means of the observation that the whole sample included both short and long hospitalizations, so that the effect of most variables can be interpreted as non- specific or confounding risk factors of lengthening.

The age of our whole sample was generally young, although the mean age of patients who were admitted longer was statistically significantly superior to the mean age of shorter admitted ones.

The demographic variables related to the length of admission, female gender and Modena, as place of residence, could represent confounding factors, since the prevalence of these variables was the most frequent in our ward. The mean age of female patients was superior to male mean age, as is commonly observed in psychiatric wards.

The relationship between psychiatric diagnosis and the expected duration of hospitalization did not show any specific connection, as other authors have evidenced ${ }^{[53,54]}$. The presence of organic comorbidity, the need of rehabilitative programs, extra psychiatric activities or in- and outpatient care network were all factors of admission lengthening, as obviously expected, because these complex activities require the collaboration of many services or professionals. The analysis of modalities of discharge confirms this observation: ordinary discharge and transfer to protected facilities, modalities which normally require long clinical activity before discharging, prolonged the length of admission.

The analysis of the longest admissions highlights that only few factors were related to the longest duration of hospitalization: female gender, older age, the presence of rehabilitative programs, extra-psychiatric clinical activities, complex pharmacotherapy and aggressiveness of patients. But the last variable, aggressiveness, was the only one statistically significant related to the lengthening of hospitalization evidenced by all the statistic tests. Therefore, we can interpret that some variables, female gender or old age, are confounding factors, as other authors noticed ${ }^{[63]}$, others, the need of complex rehabilitative programs, extra-psychiatric clinical activities or poly-therapy, are relevant risk factors of delayed discharging common to other clinical settings, whereas aggressiveness is the factor most strictly related to the lengthening of psychiatric hospitalizations.

\section{Conclusions}

Our analysis was retrospectively conducted in an acute ward, where hospitalizations are usually short, as established by Italian guidelines, but with some exceptionally long-stays defined delayed discharges. These cases stimulated our interest in researching the causes and factors that induce long-stays in psychiatry, especially in the light of Italian health care system. Currently, Italy, has the lowest number of beds for acute psychiatric admissions (1.7 per 10,000 inhabitants) compared to all other European countries and the length of hospital stay in the Italian SPDC wards is an average of 11.4 days, according to PROGRES-Acute Project, a research carried out in all Italian regions (with the exception of Sicily) from 2002 to $2003{ }^{[58]}$. After the Italian 180 Law ${ }^{[59]}$, subsequently included in the 833 Law of 23/12/1978, which represented a dramatic change in psychiatric care especially due to the complete abolition of asylum institutions, the number of hospital beds has been dramatically reduced and patients are no longer admitted to psychiatric beds in public hospitals outside of the 15-bed SPDC wards. In order to maintain therapeutic and rehabilitative outpatient care programs, residential and semi-residential facilities are available for each Mental Health Centre. According to the most recent 
estimates, in Italy 2.98 residential beds for every 10,000 inhabitants are available on average ${ }^{[60]}$. During the last years, the number of beds in residential facilities has rapidly increased in all parts of Italy, allowing a reduction in hospital admissions ${ }^{[61]}$.

Our results suggest that a wide range of factors may be responsible for the delayed discharges in psychiatry as most previous studies have already shown ${ }^{[52]}$. Similar factors, like transfer to protected facilities or activation of in- and outpatient care network, are present in other clinical settings, whereas others, like as aggressiveness, are more specific to psychiatry.

Other studies have noticed that aggressiveness can be important risk factors for lengthening in psychiatry ${ }^{[53,54,64]}$. Also, our research, that does not put in evidence any psychiatric diagnosis as possible risk factor for lengthening as other previous studies ${ }^{[53,54]}$, highlights that the dimension of aggressiveness is the most frequent component of long-stay in psychiatry. Aggressive behavior represents a severe and acute symptom of almost all psychiatric diseases, which is often responsible for psychiatric hospital admission. The aggressiveness of patient can be sufficient by itself to explain the difficulty of discharging, since it can induce a sort of pathological dependence of the patient on the institution due to the vicious circle of aggression and counter-aggression that often triggers.

We can conclude that not only complex clinical activity, represented by the need for implementing medical, psychological and rehabilitative activities, but also a specific trans-nosographic dimension, like aggressiveness can induce long-stay in psychiatry.

\section{Limits and advantages}

This study represents one of the first studies on this topic in the psychiatric field. The analysis was conducted on a large sample, for sufficiently long observation period and with many variables analyzed. Since this study used retrospective methodology, the choice of the clinical and health care organizational variables was conditioned by the availability of data. Moreover, the retrospective methodology did not permit the consideration of other kinds of factors as clinical severity.

\section{Future implications}

Our data indirectly suggest that both a more efficient out-patient care organization and a more appropriate training of professionals in managing aggressive behavior of patient can prevent the risk of long hospitalization in psychiatry. The community rehabilitative activities, which represent the most effective strategies for improving cognitive and adaptive capacities of patients, also for the case with severe disabling psychiatric conditions ${ }^{[65]}$, should be correctly integrated between in-patient and out-patient care services in order to reduce long-stay hospitalizations. Staff training should be based not only on self- confidence of dangerous situations, but on a good awareness of one's own reactive feelings towards violent patients, in order to reduce the symmetric attitude which induces an escalation of aggressiveness ${ }^{[66-68]}$.

Further prospective researches focused on the clinical issues which have arisen from this study are necessary in order to better describe the long-stay phenomenon in psychiatry.

\section{References}

[1] Rubin SG, Davies GH. Bed blocking by elderly patients in general-hospital wards. Age Ageing. 1975; 4: 142-7. PMid:1211299 http://dx.doi.org/10.1093/ageing/4.3.142

[2] Styrborn K, Thorslund M. 'Bed-blockers': delayed discharge of hospital patients in a nationwide perspective in Sweden. Health policy. 1993; 26: 155-70. http://dx.doi.org/10.1016/0168-8510(93)90116-7 
[3] Gansel Y, Danet F, Rauscher C. Long-stay inpatients in short-term emergency units in France: A case study. Soc Sci Med. 2010; 70: 501-8. PMid:19926188 http://dx.doi.org/10.1016/j.socscimed.2009.10.045

[4] Preti A, Rucci P, Gigantesco A, Santone G, Picardi A, Miglio R et al. Patterns of care in patients discharged from acute psychiatric inpatient facilities: a national survey in Italy. Soc Psychiatry Psychiatr Epidemiol. 2009; 44: 767-76. PMid:19212696 http://dx.doi.org/10.1007/s00127-009-0498-2

[5] Furlan PM, Zuffranieri M, Stanga F, Ostacoli L, Patta J, Picci RL. Four-year follow-up of long-stay patients settled in the community after closure of Italy's psychiatric hospitals. Psychiatr Serv. 2009; 60: 1198-202. PMid:19723734 http://dx.doi.org/10.1176/appi.ps.60.9.1198

[6] Trieman N, Leff J, Glover G. Outcome of long stay psychiatric patients resettled in the community: prospective cohort study. BMJ. 1999; 319: 13-6. PMid:10390451 http://dx.doi.org/10.1136/bmj.319.7201.13

[7] Bryan K, Gage H, Gilbert K. Delayed transfers of older people from hospital: Causes and policy implications. Health Policy. 2006; 76: 194-201. PMid:16040152 http://dx.doi.org/10.1016/j.healthpol.2005.06.005

[8] Styrborn K, Thorslund M. Delayed discharge of elderly hospital patients-a study of bed-blockers in a health care district in Sweden. Scand J Soc Med. 1993; 21: 272-80. PMid:8310280

[9] Glasby J, Lester H. Delayed hospital discharge and mental health: The policy implications of Recent Research. Social Policy \& Administration. 2004; 38: 744-57. http://dx.doi.org/10.1111/j.1467-9515.2004.00416.x

[10] Vaughan B, Withers G. Bed-blocking. Acute distress. Health Serv J. 2002; 112: 24-7. PMid:12038234

[11] Carey K. Hospital length of stay and cost: a multilevel modeling analysis. Health Services and Outcome Research Methodology. 2002; 3: 41-56. http://dx.doi.org/10.1023/A:1021530924455

[12] Glasby J, Littlechild R, Pryce K. Show me the way to go home: a narrative review of the literature on delayed hospital discharges and older people - research note. Br J Soc Work. 2004; 34: 1189-1197. http://dx.doi.org/10.1093/bjsw/bch136

[13] Dainty P, Elizabeth J. Timely discharge of older patients from hospital: improving the process. Clin Med. 2009 ; 9: 311-4. PMid:19728500 http://dx.doi.org/10.7861/clinmedicine.9-4-311

[14] Lees L, Holmes C. Estimating date of discharge at ward level: a pilot study. Nurs Stand. 2005; 19: 40-3. PMid:15658837

[15] The Joint Commission. Specifications Manual for National Hospital Inpatient Quality Measures. 2012. Available from: http://www.jointcommission.org/specifications_manual_for_national_hospital_inpatient_quality_measures.aspx. (28 December 2012, date last accessed).

[16] Alper E, A O'Malley T, Greenwald J. Hospital discharge. 2012. Available from: http://www.uptodate.com/contents/hospital-discharge. (28 December 2012, date last accessed).

[17] Walker C, Hogstel MO, Curry LC. Hospital discharge of older adults. How nurses can ease the transition. Am J Nurs. 2007; 107: 60-70. PMid:17519609 http://dx.doi.org/10.1097/01.NAJ.0000271853.38215.20

[18] Pertile R, Donisi V, Grigoletti L, Angelozzi A, Zamengo G, Zulian G, et al. DRGs and other patient-, service- and area-level factors influencing lengh of stay in acute psychiatric wards: the Veneto Region experience. Soc Psychiatry Psychiatr Epidemiol. 2011; 46: 651-60. PMid:20473480 http://dx.doi.org/10.1007/s00127-010-0231-1

[19] Glasby J, Littlechild R, Pryce K. All dressed up but nowhere to go? Delayed hospital discharges and older people. J Health Serv Res Policy. 2006; 11: 52-8. PMid:16378533 http://dx.doi.org/10.1258/135581906775094208

[20] Katsaliaki K, Brailsford S, Browning D, Knight P. Mapping care pathways for the elderly. J Health Organ Manag. $2005 ; 19: 57-72$. PMid:15938602 http://dx.doi.org/10.1108/14777260510592130

[21] Bendz M, Castledine G, Söderback I, Carvalho G, Sapountzi-Krepia D. Discharge of frail older people from acute hospitals across Europe. Br J Nurs. 2002; 11: 111-5. PMid:11823738

[22] Victor CR, Healy J, Thomas A, Seargeant J. Older patients and delayed discharge from hospital. Health Soc Care Community. 2000; 8: 443-452. PMid:11560715 http://dx.doi.org/10.1046/j.1365-2524.2000.00270.x

[23] El-Darzi E, Vasilakis C, Chaussalet T, Millard PH. A simulation modelling approach to evaluating length of stay, occupancy, emptiness and bed blocking in a hospital geriatric department. Health Care Manag Sci. 1998; 1: 143-9. http://dx.doi.org/10.1023/A:1019054921219

[24] Manzano-Santaella A. From bed-blocking to delayed discharges: precursors and interpretations of a contested concept. Health Serv Manage Res. 2010; 23: 121-7. PMid:20702889 http://dx.doi.org/10.1258/hsmr.2009.009026

[25] Baumann M, Evans S, Perkins M, Curtis L, Netten A, Fernandez JL, et al. Organisation and features of hospital, intermediate care and social services in English sites with low rates of delayed discharge. Health Soc Care Community. 2007; 15: 295-305. PMid:17578390 http://dx.doi.org/10.1111/j.1365-2524.2007.00697.x

[26] Mayhew L, Lawrence D. The costs and service implications of substituting intermediate care for acute hospital care. Health Serv Manage Res. 2006; 19: 80-93. PMid:16643707 http://dx.doi.org/10.1258/095148406776829077 
[27] Paton JM, Fahy MA, Livingston GA. Delayed discharge-a solvable problem? The place of intermediate care in mental health care of older people. Aging Ment Health. 2004; 8: 34-9. PMid:14690866 http://dx.doi.org/10.1080/13607860310001613310

[28] Bryan K. Policies for reducing delayed discharge from hospital. Br Med Bull. 2010; 95: 33-46. PMid:20647227 http://dx.doi.org/10.1093/bmb/ldq020

[29] Kumar PN, Shinge N, Parameshwar S. Bed blockers: a study on the elderly patients in a teaching hospital in India. Online J Health and Allied Scs. 2010; 9(1): 6.

[30] Kydd A. The patient experience of being a delayed discharge. J Nurs Manag. 2008; 16: 121-6. PMid:18269541 http://dx.doi.org/10.1111/j.1365-2834.2008.00848.x

[31] Béland F, Bergman H, Lebel P, Clarfield AM, Tousignant P, Contandriopoulos AP, et al. A system of integrated care for older persons with disabilities in Canada: results from a randomized controlled trial. J Gerontol A Biol Sci Med Sci. 2006; 61: 367-73. PMid:16611703 http://dx.doi.org/10.1093/gerona/61.4.367

[32] Crotty M, Whitehead CH, Wundke R, Giles LC, Ben-Tovim DI, Phillips PA. Transitional care facility for elderly people in hospital awaiting a long term care bed: randomized controlled trial. BMJ. 2005; 331(7525):1110. PMid:1869444

[33] Falcone D, Bolda E, Leak SC. Waiting for placement: an exploratory analysis of determinants of delayed discharges of elderly hospital patients. Health Serv Res. 1991; 26: 339-74.

[34] Mackenzie-Davies N, Mansell J. Assessment and treatment units for people with intellectual disabilities and challenging behaviour in England: an exploratory survey. J Intellect Disabil Res. 2007; 51: 802-11. PMid:17803498 http://dx.doi.org/10.1111/j.1365-2788.2007.00963.x

[35] Ruggerini C, Guaraldi GP, Russo A, Neviani V, Castagnini A. Integration of a psychiatric service in a long-term charitable facility for people with intellectual disabilities: a 5-year medication survey. Res Dev Disabil. 2004; 25: 431-41. PMid:15217672 http://dx.doi.org/10.1016/j.ridd.2003.09.004

[36] Hendy P, Patel JH, Kordbacheh T, Laskar N, Harbord M. In-depth analysis of delays to patient discharge: a metropolitan teaching hospital experience. Clin Med. 2012; 12(4): 320-3. PMid:22930874 http://dx.doi.org/10.7861/clinmedicine.12-4-320

[37] Angelillo IF, Ricciardi G, Nante N, Boccia A, Bianco A, La Torre G, et al. Appropriateness of hospital utilization in Italy. Public Health. 2000; 114: 9-14. PMid:10787019

[38] Fisher WH, Barreira PJ, Geller JL, White AW, Lincoln AK, Sudders M. Long-stay patients in state psychiatric hospitals at the end of the 20th century. Psychiatr Serv. 2001; 52: 1051-6. PMid:11474050 http://dx.doi.org/10.1176/appi.ps.52.8.1051

[39] Panis LJ, Gooskens M, Verheggen FW, Pop P, Prins MH. Predictors of inappropriate hospital stay: a clinical case study. Int J Qual Health Care. 2003; 15: 57-65. PMid:12630801 http://dx.doi.org/10.1093/intqhe/15.1.57

[40] Benson RT, Drew JC, Galland RB. A waiting list to go home: an analysis of delayed discharges from surgical beds. Ann R Coll Surg Engl. 2006; 88: 650-2. PMid:17132314 http://dx.doi.org/10.1308/003588406X149246

[41] Gertman PM, Restuccia JD. The Appropriateness evaluation protocol: a technique for assessing unnecessary days of hospital care. Med Care. 1981; 19: 855-871. PMid:7196975 http://dx.doi.org/10.1097/00005650-198108000-00005

[42] Guilé R, Leux C, Paillé C, Lombrail P, Moret L. Validation of a tool assessing appropriateness of hospital days in rehabilitation centres. Int J Qual Health Care. 2009; 21: 198-205. PMid:19251730 http://dx.doi.org/10.1093/intqhe/mzp008

[43] Soria-Aledo V, Carrillo-Alcaraz A, Campillo-Soto A, Flores-Pastor B, Leal-Llopis J, Fernández-Martín MP, et al. Associated factors and cost of inappropriate hospital admissions and stays in a second-level hospital. Am J Med Qual. 2009; 24 : 321-32. PMid:19515942 http://dx.doi.org/10.1177/1062860609337252

[44] Hwang JI, Kim J, Jang W, Park JW. Inappropriate hospitalization days in Korean oriental medicine hospitals. Int J Qual Health Care. 2011; 23: 437-44. PMid:21669970 http://dx.doi.org/10.1093/intqhe/mzr028

[45] Attena F, Agozzino E, Troisi MR, Granito C, Del Prete U. Appropriateness of admission and hospitalization days in a specialist hospital. Ann Ig. 2001; 13: 121-7. PMid:11414101

[46] McDonagh MS, Smith DH, Goddard M. Measuring appropriate use of acute beds. A systematic review of methods and results. Health policy. 2000; 53: 157-84. http://dx.doi.org/10.1016/S0168-8510(00)00092-0

[47] Barrette PA. 1,005 delayed days: a study of adult psychiatric discharge. Hosp Community Psychiatry. 1981; 32: 266-8. PMid:7227988

[48] Lelliott P, Wing J. A national audit of new long-stay psychiatric patients: part II. Impact on services. Br J Psychiatry. 1994; 165: 170-8. PMid:7953030 http://dx.doi.org/10.1192/bjp.165.2.170

[49] Zeldow PB, Taub HA. Evaluating psychiatric discharge and aftercare in a VA medical center. Hosp Community Psychiatry. 1981; 32: 57-8. PMid:6257608

[50] Kelly A, Watson D, Raboud J, Bilsker D. Factors in delays in discharge from acute-care psychiatry. Can J Psychiatry. 1998; 43: 496-501. PMid:9653534 
[51] Koffman J, Fulop NJ. Homelessness and the use of acute psychiatric beds: findings from one-day survey of adult acute and low-level secure psychiatric patients in North and South Thames regions. Health Soc Care Community. 1999; 7: $140-147$. PMid:11560630 http://dx.doi.org/10.1046/j.1365-2524.1999.00156.x

[52] Lewis R, Glasby J. Delayed discharge from mental health hospitals: results of an English postal survey. Health Soc Care Community. 2006; 14: 225-30. PMid:16650119 http://dx.doi.org/10.1111/j.1365-2524.2006.00614.x

[53] Warnke I, Rössler W, Herwig U. Does psychopathology at admission predict the length of inpatient stay in psychiatry? Implications for financing psychiatric services. BMC Psychiatry. 2011; 11: 120. PMid:21801366 http://dx.doi.org/10.1186/1471-244X-11-120

[54] Gigantesco A, de Girolamo G, Santone G, Miglio R, Picardi A. Long-stay in short-stay inpatient facilities: risk factors and barriers to discharge. BMC Public Health. 2009; 9: 306. PMid:19698136 http://dx.doi.org/10.1186/1471-2458-9-306

[55] Ministero della Salute. Legge 13 maggio 1978 , n. 180. Accertamenti e trattamenti sanitari volontari e obbligatori. (G.U. Serie Pregressa, n. 133 del 16 maggio 1978). Available from: http://www.trovanorme.salute.gov.it/dettaglioAtto?id=36714. (28 December 2012, date last accessed).

[56] Ministero del Lavoro, della Salute e delle Politiche Sociali. (2008). Classificazione delle malattie e dei traumatismi, degli interventi chirurgici e delle procedure diagnostiche e terapeutiche. Versione italiana della ICD-9-CM. "International Classification of Diseases-9th revision-Clinical Modification" 2007. Roma: Istituto Poligrafico e Zecca dello Stato.

[57] Pagano M, Gauvreau K. Fondamenti di biostatistica. II edizione. 2003. Napoli: Idelson Gnocchi

[58] de Girolamo G, Picardi A, Micciolo R, Falloon I, Fioritti A, Morosini P, PROGRES Group. Residential care in Italy. National survey of non-hospital facilities. Br J Psychiatry. 2002; 181: 220-5. PMid:12204926 http://dx.doi.org/10.1192/bjp.181.3.220

[59] Burti L. The Italian reform, 18 years after: history, execution and consequences. Sante Ment Que. 1997; 22: 71-87. PMid:9534578 http://dx.doi.org/10.7202/032416ar

[60] Lora A. An overview of the mental health system in Italy. Ann Ist Super Sanità. 2009; 45: 5-16. PMid:19567972

[61] Gaddini A, Biscaglia L, Bracco R, de Girolamo G, Miglio R, Norcio B, et al. A one-day census of acute psychiatric inpatient facilities in Italy: findings from the PROGRES-Acute Project. Psychiatr Serv. 2008; 59: 722-4. PMid:18586987 http://dx.doi.org/10.1176/appi.ps.59.7.722

[62] Hopko DR, Lachar D, Bailley SE, Varner RV. Assessing predictive factors for extended hospitalization at acute psychiatric admission. Psych Serv. 2001; 52 (Suppl 10): 1367-73. http://dx.doi.org/10.1176/appi.ps.52.10.1367

[63] Rabinowitz J, Mark M. Risk factors for violence among long-stay psychiatric patients: national study. Acta Psychiatr Scand. 1999; 99 (Suppl 5): 341-7. PMid:10353449 http://dx.doi.org/10.1111/j.1600-0447.1999.tb07239.x

[64] Barbato A, D'Avanzo B, Rocca G, Amatulli A, Lampugnani D. A study of long-stay patients resettled in the community after closure of a psychiatric hospital in Italy. Psychiatr Serv. 2004; 55: 67-70. PMid:14699203 http://dx.doi.org/10.1176/appi.ps.55.1.67

[65] Stubbs B, Leadbetter D, Paterson B, Yorston G, Knight C, Davis S. Physical intervention: a review of the literature on its use, staff and patient views, and the impact of training. J Psychiatr Ment Health Nurs. 2009; 16: 99-105. PMid:19192092 http://dx.doi.org/10.1111/j.1365-2850.2008.01335.x

[66] Ferri P, Reggiani F, Di Lorenzo R. Aggressive behavior toward nursing staff in three different health care settings. Prof Inf. 2011; 64: 143-150. PMid:22044544

[67] Di Lorenzo R, Ferrara M, Baraldi S, Mimmi S, Rigatelli M. Physical restraints in an Italian psychiatric ward: clinical reasons and staff organization problems. Perspect Psychiatr Care. 2012; 48(2): 95-107. PMid:22458723

http://dx.doi.org/10.1111/j.1744-6163.2011.00308.x 